\title{
Overriding Aorta
}

National Cancer Institute

\section{Source}

National Cancer Institute. Overriding Aorta. NCI Thesaurus. Code C124569.

A congenital anatomic anomaly in which the aorta is positioned directly above a ventricular septal defect, thus receiving blood from both the right and left ventricles, resulting in an overall decrease In oxygenated haemoglobin and tissue cyanosis. 